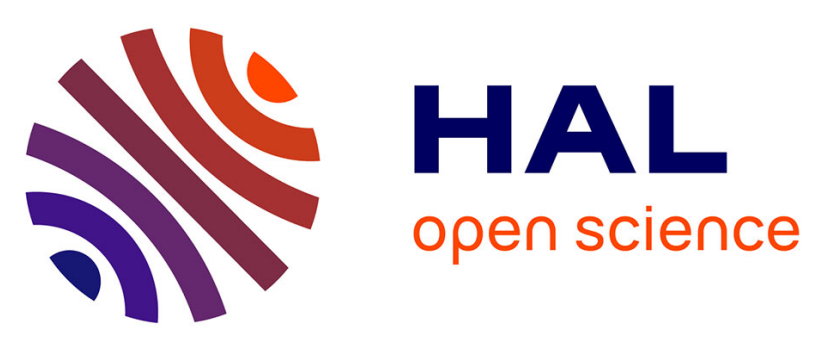

\title{
Stable Formyl Peptide Receptor Agonists That Activate the Neutrophil NADPH-oxidase Identified Through Screening of a Compound Library.
}

Huamei Forsman, Christina Kalderén, Anna Nordin, Erik Nordling, Annika Jernmalm Jensen, Claes Dahlgren

\section{To cite this version:}

Huamei Forsman, Christina Kalderén, Anna Nordin, Erik Nordling, Annika Jernmalm Jensen, et al.. Stable Formyl Peptide Receptor Agonists That Activate the Neutrophil NADPH-oxidase Identified Through Screening of a Compound Library.. Biochemical Pharmacology, 2010, 81 (3), pp.402. 10.1016/j.bcp.2010.11.005 . hal-00654976

\section{HAL Id: hal-00654976 https://hal.science/hal-00654976}

Submitted on 24 Dec 2011

HAL is a multi-disciplinary open access archive for the deposit and dissemination of scientific research documents, whether they are published or not. The documents may come from teaching and research institutions in France or abroad, or from public or private research centers.
L'archive ouverte pluridisciplinaire HAL, est destinée au dépôt et à la diffusion de documents scientifiques de niveau recherche, publiés ou non, émanant des établissements d'enseignement et de recherche français ou étrangers, des laboratoires publics ou privés. 


\section{Accepted Manuscript}

Title: Stable Formyl Peptide Receptor Agonists That Activate the Neutrophil NADPH-oxidase Identified Through Screening of a Compound Library.

Authors: Huamei Forsman, Christina Kalderén, Anna Nordin, Erik Nordling, Annika Jernmalm Jensen, Claes

Dahlgren<ce:footnote id="fn0005" ><ce:note-para $>$ Present address: Division of Chemical Biology, Department of Medical Biochemistry and Biophysics, Karolinska Institutet, SE-171 77 Stockholm, Sweden.</ce:note-para ></ce:footnote>

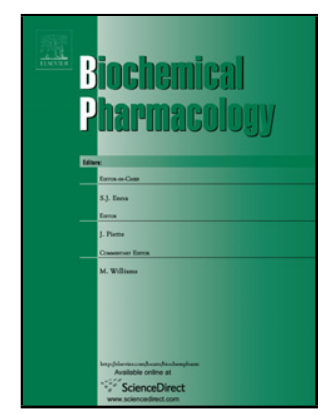

PII: S0006-2952(10)00802-6

DOI: doi:10.1016/j.bcp.2010.11.005

Reference: BCP 10755

To appear in: $\quad B C P$

Received date: $\quad 23-8-2010$

Revised date: $\quad 14-10-2010$

Accepted date: $\quad 4-11-2010$

Please cite this article as: Forsman H, Kalderén C, Nordin A, Nordling E, Jensen AJ, Dahlgren C, Stable Formyl Peptide Receptor Agonists That Activate the Neutrophil NADPH-oxidase Identified Through Screening of a Compound Library., Biochemical Pharmacology (2008), doi:10.1016/j.bcp.2010.11.005

This is a PDF file of an unedited manuscript that has been accepted for publication. As a service to our customers we are providing this early version of the manuscript. The manuscript will undergo copyediting, typesetting, and review of the resulting proof before it is published in its final form. Please note that during the production process errors may be discovered which could affect the content, and all legal disclaimers that apply to the journal pertain. 


\title{
Stable Formyl Peptide Receptor Agonists That Activate the
}

\section{Neutrophil NADPH-oxidase Identified Through Screening of a}

\section{Compound Library.}

\author{
Huamei Forsman ${ }^{1}$, Christina Kalderén ${ }^{2}$, Anna Nordin ${ }^{1}$, Erik Nordling ${ }^{2}$, Annika \\ Jernmalm Jensen $^{2,3}$, and Claes Dahlgren ${ }^{1, *}$ \\ ${ }^{1}$ Department of Rheumatology and Inflammation Research, Institute of Medicine, University \\ of Göteborg, Sweden \\ ${ }^{2}$ Biovitrum AB, 11276 Stockholm, Sweden \\ ${ }^{3}$ Present address: Division of Chemical Biology, Department of Medical Biochemistry and \\ Biophysics, Karolinska Institutet, SE-171 77 Stockholm, Sweden
}

\author{
*Correspondence to: \\ Claes Dahlgren \\ Department of Rheumatology and Inflammation Research, University of Göteborg \\ Box 480, S-405 30 Göteborg, Sweden \\ Phone: +46-313424683; Cell phone: +46-31708116383; \\ e-mail:Claes.Dahlgren@microbio.gu.se
}

Key words: chemoattractant receptors; formyl peptide; receptor agonists; NADPH-oxidase; library screen 


\begin{abstract}
The neutrophil formyl peptide receptors (FPR1 and FPR2) are G-protein coupled receptors that can induce pro-inflammatory as well as anti-inflammatory activities when activated. Accordingly, these receptors may become therapeutic targets for the development of novel drugs to be used for reducing the inflammation induced injuries in asthma, rheumatoid arthritis, Alzheimer's disease, cardiovascular diseases and traumatic shock. We screened a library of more then $50 \mathrm{~K}$ small compounds for an ability of the compounds to induce a transient rise in intracellular $\mathrm{Ca}^{2+}$ in cells transfected to express FPR2 (earlier called FPRL1 or the lipoxin $\mathrm{A}_{4}$ receptor). Ten agonists hits were selected for further analysis representing different chemical series and five new together with five earlier described molecules were further profiled.. Compounds 1 - 10 gave rise to a calcium response in the FPR2 transfectants with $\mathrm{EC}_{50}$ values ranging from $4 \times 10^{-9} \mathrm{M}$ to $2 \times 10^{-7} \mathrm{M}$. All 10 compounds activated human neutrophils to release superoxide, and based on the potency of their activity, the three most potent activators of the neutrophil NADPH-oxidase were further characterized. These three agonists were largely resistant to inactivation by neutrophil produced reactive oxygen species and shown to trigger the same functional repertoire in neutrophils as earlier described peptide agonists. Accordingly they induced chemotaxis, granule mobilization and secretion of superoxide. Interestingly, the oxidase activity was largely inhibited by cyclosporine $\mathrm{H}$, an FPR1 selective antagonist, but not by PBP10, an FPR2 selective inhibitor, suggesting that FPR1 is the preferred receptor in neutrophils for all three agonists.
\end{abstract}

Key words: neutrophils, formyl peptide receptors, receptor antagonists, signal transduction, NADPH-oxidase, chemoattractant receptors. 


\section{Introduction}

Professional phagocytes such as neutrophil granulocytes play important roles in host defence against pathogenic microbes, but they are also key regulators in the fine-tuning of inflammatory reactions. The functional repertoires of these cells are triggered and regulated through binding of different inflammatory mediators that are recognized by specific cell surface receptors expressed on resting or primed cells $[1,2]$. Receptors that belong to the "Gprotein coupled, seven transmembrane family of receptors (GPCRs)" are well represented on neutrophils, and the function of one of these, the formyl peptide receptor (FPR1) has been extensively studied. This receptor is a member of the chemoattractant receptor subfamily that recognizes $\mathrm{N}$-formylated peptides [3-5]. As such peptides are derived from bacterial or mitochondrial proteins, it has been proposed that a primary FPR1 function is to promote trafficking of phagocytic myeloid cells to sites of infection and tissue damage, where they exert antibacterial effector functions and clear cell debris. Accordingly the prototype agonist formylmethionyl-leucyl-phenylalanine (fMLF) is a bacterial produced high-affinity FPR1 agonist that triggers a variety of biologic activities in neutrophils, including chemotaxis, granule secretion, cytokine production, and superoxide release, the latter generated through an activation of an electron transporting NADPH-oxidase [6]. The reactive oxygen species (ROS) derived from the activated NADPH-oxidase are essential for a successful clearance of bacteria during infection as illustrated by the fact that patients lacking a functional oxidase suffer repeatedly from severe bacterial infections [7]. In addition to FPR1, neutrophils express also a closely related receptor, FPR2, that belongs to the same receptor family $[4,5]$. This receptor was initially orphan, but over the last 15 years, a wide range of agonists have been identified. All peptide 
agonists described but two, possess the same pro-inflammatory activities as the FPR1 agonists. The two exceptions are i) peptides cleaved off from the $\mathrm{N}$-terminus of the calcium regulated protein annexin I [8,9] and ii) a 21 amino acids long synthetic peptide identified through a library screen [10]. Activation of FPR2 with these two peptide agonists triggers a unique signalling pathway that inhibits neutrophil function and induces anti-inflammatory activities in different model systems. The same functional link - FPR2 and induction of antiinflammatory activities - has been established for the eicosanoid $\mathrm{LXA}_{4}$ [11], but our earlier published data suggest that this lipid mediator uses a receptor distinct from FPR2 [12, 13]. The eicosanoid is easily oxidized and by that biologically inactivated [11-13], and this is true also for many of the peptide agonists [14].

Through the use of small molecule libraries screening, a series of non-peptide agonists for the FPRs have been identified during the last couple of years. When investigated, the functional repertoire triggered by small non-peptide agonists such as the Quinazolinonoe (Quin-C1) derivatives that selectively bind FPR2 [15],AG14 that selectively binds FPR1 [16], and pyrazolone that binds both receptors [17], resembles that of the pro-inflammatory peptides and not that of the anti-inflammatory agonists. Using a chemolibrary screening approach it was recently shown that agonists of FPR1/FPR2 include compounds with wide chemical diversity [18]. Owing to the fact that the function of FPR2 during recent years has been linked not only to innate immune functions but also to chronic inflammation in systemic inflammatory and auto-immune diseases, clinically oriented research focusing on FPR2 has been carried out.

The aim of this study was to identify novel small molecule FPR2 agonists by screening a small molecule library, and of particular interest was to determine the ability of the new agonists, to activate the neutrophil NADPH-oxidase. This could possibly be used to determine if a compound should be regarded as pro-inflammatory or have the potential of being anti- 
inflammatory. After screening more than 50000 compounds, 5 structurally diverse FPR2

agonists were selected (from the more then 500 hits that were confirmed as agonists from the screen) and further investigated together with five "hits" identical to earlier described FPR2 agonists. All the agonists were found to activate the neutrophils to produce superoxide. The three most potent agonists, one earlier described pyrazolone compound [19] and two new compound, were further characterized and found to be insensitive to inactivation by oxidants and possess all the functional characteristics of earlier described pro-inflammatory peptide agonists. Upon binding to human neutrophils, they induce granule mobilization, directional cellular migration and production of superoxide anion. Our data also show that these novel agonists preferentially use FPR1, and in contrast to many of the earlier described peptide agonists, they are resistant to oxidation by neutrophil-derived oxygen radicals. We suggest that these small non-peptide compounds could serve as good tools for enhanced understanding of the structure-function relationships of FPRs and for in vitro/in vivo therapeutic studies in which long lived agonist are required. 


\section{MATERIAL AND METHODS}

\subsection{Materials.}

Part of the chemical library was selected on the basis of diversity from Biovitrum and iNovica compound collections which consists of 40000 compounds. The other part (an additional 10 000 compounds) was based on reference compounds collected from the literature ([19], http://www.wipo.int/pctdb/en/wo.jsp?wo=2005047899), and used as input to computational techniques allowing us to detect compounds with similar properties. In order to do this a pharmacophore was built in Phase [20] and it consisted of a central acceptor/donor pair flanked on one side of an acceptor and a hydrophobic group and on the other side by one aromatic group and one hydrophobic group (see supplementary Fig 1). A Tuplet hypothesis was then constructed using triplets [21], and used in parallel with the Phase pharmacophore to find matching compounds. The search results were used to select targeted libraries that showed a large proportion of hits in either of the searches. In addition discrete compounds that were found using either method were also selected for the screening, and the additional 10000 compounds were selected in this way. The purity and identity of the used compounds were verified using NMR spectroscopy, HPLC, and mass spectroscopy. The compounds were dissolved in DMSO at a concentration of $10 \mathrm{mM}$ and stored at $-80^{\circ} \mathrm{C}$. Isoluminol, TNF- $\alpha$, fMLF, as well as C5a were obtained from Sigma Chemical Co. (St. Louis, Mo., USA). IL-8 was from R\&D systems (Minneapolis, MN., USA). The hexapeptide Trp-Lys-Tyr-Met-ValMet-NH2 (WKYMVM) was synthesized and purified by HPLC by Alta Bioscience (University of Birmingham, Birmingham, United Kingdom). Horse radish peroxidase (HRP) was purchased from Boehringer-Mannheim (Mannheim, Germany). Dextran and Ficoll-Paque were from Pharmacia (Uppsala, Sweden). The receptor antagonist Trp-Arg-Trp-Trp-Trp-Trp$\mathrm{CONH}_{2}\left(\mathrm{WRW}_{4}\right)$ was from GenScript Corp (Piscataway,NJ., USA) and cyclosporin $\mathrm{H}$ was kindly provided by Novartis Pharma (Basel, Switzerland). The peptides/receptor antagonists 
were dissolved in dimethyl sulfoxide to $10^{-2} \mathrm{M}$ and stored at $-80^{\circ} \mathrm{C}$ until use. Further dilutions were made in Krebs-Ringer phosphate buffer containing glucose $(10 \mathrm{mM}), \mathrm{Ca}^{2+}(1 \mathrm{mM})$, and $\mathrm{Mg}^{2+}(1.5 \mathrm{mM})(\mathrm{KRG} ; \mathrm{pH} 7.3)$.

The peptide QRLFQVKGRR (gelsolin residues 160-169), prepared by solid phase peptide synthesis and coupled to rhodamine as described [22].

\subsection{Screening assay with FPR2 transfectants -- determination of changes in cytosolic}

calcium. CHO-K1 cells stably expressing the human FPR2 and Galpha16 were plated in HAMSF12 with glutamax, $10 \%$ dialyzed FBS $250 \mathrm{mg} / \mathrm{l}$ zeocin and $400 \mathrm{mg} / \mathrm{l}$ geneticin (GIBCO/Invitrogen AB, Stockholm, Sweden) at a density of 10000 cells/well and incubated at $37^{\circ} \mathrm{C}$ and $5 \% \mathrm{CO} 2$ over night. After two washes with assay buffer, HBSS with $20 \mathrm{mM}$ HEPES (GIBCO/Invitrogen AB, Stockholm, Sweden) cells were loaded with $3.6 \mu \mathrm{M}$ Fluo4 AM (Molecular Probes, Eugene, OR, USA) diluted in assay buffer, including $2.5 \mathrm{mM}$ probenecid (Sigma Chemical Co. (St. Louis, Mo., USA) for $60 \mathrm{~min}$, at $37^{\circ} \mathrm{C}$. Prior to measurement cells were washed and incubated in assay buffer for another five minutes. Compounds, dissolved in DMSO at a concentration of $10 \mathrm{mM}$ were diluted to $0.08 \mathrm{mM}$ in assay buffer. In FLIPR 2 (Molecular Devices Inc., Sunnyvall, CA., USA) cells were stimulated with compounds at a final concentration of $20 \mu \mathrm{M}$ and changes of cytosolic calcium were measured. Excitation wavelength was $488 \mathrm{~nm}$ and a 510-570 $\mathrm{nm}$ filter was used for emission measurements. Maximum emission data from each compound stimulation was collected and percentage of response elicited by $2 \mathrm{nM}$ WKYMVm-peptide was calculated. Compounds that induced a calcium response over $60 \%$ of the response elicited by $2 \mathrm{nM}$ WKYMVm-peptide were defined as hits. All hits were counter screened in CHO-K1 cells transfected with G-alpha16 to exclude unspecific calcium agonists. 
Selected hits were confirmed in calcium release analysis in FPR2 and Galpha16 transfected

cells described above in a dose dependent manner from $20 \mu \mathrm{M}$ to $3.4 \mathrm{pM}$ in 11 steps.

The ability to activate FPR1 transfectants was determined in a calcium release assay basically as described above. CHO-K1 cells stably expressing the human FPR1 and Galpha16 were plated as described above (but with $800 \mathrm{mg} / \mathrm{l}$ of geneticin) at a density of 10000 cells/well and incubated at $37^{\circ} \mathrm{C}$ and $5 \% \mathrm{CO} 2$ over night. Cells were labeled with Fluo4 and the change in intracellular calcium ions was determined as described above.

\subsection{Isolation of human neutrophils}

Neutrophil granulocytes were isolated from buffy coats obtained from healthy adults [23]. After dextran sedimentation at $1 \mathrm{x} \mathrm{g}$, hypotonic lysis of the remaining erythrocytes, and centrifugation in a Ficoll-Paque gradient, the neutrophils were washed twice and resuspended $\left(1 \times 10^{7} / \mathrm{ml}\right)$ in KRG. The cells were stored on melting ice and used within $120 \mathrm{~min}$ of preparation.

\subsection{Neutrophil NADPH-oxidase activity}

Neutrophil superoxide anion production was determined using an isoluminol-enhanced chemiluminescence (CL) system $[24,25]$. The CL activity was measured in a 6-channel Biolumat LB 9505 (Berthold Co, Wildbad, Germany) using disposable 4-ml polypropylene tubes with a $1-\mathrm{ml}$ reaction mixture. Tubes containing isoluminol $\left(2 \times 10^{-5} \mathrm{M}\right)$, horseradish peroxidase (HRP, $4 \mathrm{U})$, and neutrophils $\left(2 \times 10^{5} / \mathrm{ml}\right)$ were allowed to equilibrated for 5 minutes at $37^{\circ} \mathrm{C}$, after which $0.1 \mathrm{ml}$ of stimuli was added and the light emission was recorded continuously. All experiments (with resting as well as primed cells) were performed with neutrophils in suspension. 
By a direct comparison of the superoxide dismutase (SOD) inhibitable reduction of cytochrome C and SOD inhibitable CL, 7.2 $\times 10^{7}$ counts were found to correspond to a production of $1 \mathrm{nmol}$ of superoxide (a millimolar extinction coefficient for cytochrome $\mathrm{C}$ of 21.1 was used; details about the $\mathrm{CL}$ technique is given in $[25,26])$.

\subsection{Chemotaxis assay}

Neutrophil migration was determined using a 96-well microplate chemotaxis chambers with hydrophobic filters of pore size $3 \mu \mathrm{m}$ (ChemoTx; Neuro Probe Inc., Gaithersburg, MD, USA) according to the instructions given by the manufacturer. In short, compounds and the positive control, $N$-formyl-Met-Leu-Phe, fMLF $\left(10^{-8} \mathrm{M}\right)$ were added to wells in the lower chamber. All dilutions were made in KRG buffer supplemented with 0.3\% BSA. Cell suspensions (30 $\mu l)$ neutrophils $\left(10^{6} / \mathrm{ml}\right)$ were placed on top of the filters and allowed to migrate for $90 \mathrm{~min}$ at $37^{\circ} \mathrm{C}$. Cell migration was examined under microscope. For quantification, the content of myeloperoxidase was assessed in the lysates of transmigrated cells by adding a peroxidase substrate $o$-phenylenediamine.

\subsection{Cell surface receptor exposure by FACS analysis}

To determine the effect of compounds on cell surface CR3 exposure, cells were incubated with various concentrations of neutrophil activators at $37^{\circ} \mathrm{C}$ for $15 \mathrm{~min}$. After which the cells were labelled with a PE-conjugated CR3 antibody on ice for $30 \mathrm{~min}$. The amount of specifically bound antibody after washing off excess of unbound antibody was determined by flow cytometry.

The release of myeloperoxidase (MPO), an azurophil granule marker of importance for inactivation of chemoattractants [14], was determined as described earlier [27] 
1

2

3

4

5

6

7

8

10

11

12

13

14

15

16

17

18

19

20

21

22

23

24

25

26

27

28

29

30

31

32

33

34

35

36

37

38

39

40

41

42

43

44

45

46

47

48

49

50

51

52

53

54

55

56

57

58

59

60

61

62

63

64

65

Page 10 of 35 


\section{RESULTS}

\subsection{Identification of novel non-peptide molecules that interact with FPR2}

We used a small molecule screening set approach to identify novel agonists for formyl peptide receptor 2 (FPR2). Transfected CHO cells stably expressing FPR2 were loaded with Fluo4 AM and then stimulated with 50000 compounds in 384 format FLIPR and analyzed for increase in the concentration of cytosolic calcium. The screen was performed at $20 \mu \mathrm{M}$ to identify only agonists.

Out of the $50 \mathrm{~K}$ compounds screened, more then 500 was confirmed as agonist hits and five compounds representing different chemical series were selected for further profiling. In addition, five earlier described FPR2 agonists (compound 1,2,3,4 and 7 in Fig.1) were also profiled. All 10 compounds were found to trigger an intracellular $\mathrm{Ca}^{2+}$ response in FPR2 expressing cells. The $\mathrm{EC}_{50}$ values for the different compounds were determined and were found to vary from $4 \times 10^{-9}$ to $2 \times 10^{-7} \mathrm{M}$ (Fig 1). Based on the activity, they could be divided into three groups. The $\mathrm{EC}_{50}$ value for compound 8 and 9 was higher (in the $10^{-7} \mathrm{M}$ range) than the corresponding values for compound 1, 2, 3, 6 and 7 (in the $10^{-8} \mathrm{M}$ range), whereas the most potent compounds (the compounds 4,5 and, 10) were active in the $\mathrm{nM}$ concentration range (Fig 1).

The potential pro-inflammatory activity of FPR2 binding compounds derived from the small molecule library was investigated using human neutrophils as model cells and the NADPHoxidase mediated superoxide production as readout system.

\section{The non-peptide FPR2 agonists activate neutrophils to produce superoxide anions}

The abilities of the 10 compounds identified as FPR2 agonists to induce a respiratory burst activity in resting and TNF- $\alpha$ primed neutrophils were determined. All compounds induced a 
neutophil respiratory burst and with respect to the potency they grouped in the same way as described above. The compounds 8 and 9 induced a respiratory burst only in TNF-a primed cells and in concentrations higher that $1 \mu \mathrm{M}$, whereas the compounds 1, 2, 3, 6 and 7 triggered also resting cells to produce superoxide anions (data not shown). The three compounds (4, 5 and 10) that had the highest activity in the calcium assay, were the most potent also in triggering a respiratory burst, and a robust superoxide production was induced in resting cells (Fig2). The response induced in TNF- $\alpha$ primed cells were strongly increased with all compounds including the three most potent ones (data not shown). We decided to characterize the activities induced in neutrophils by the three most active compounds 4, 5 and, 10, in more detail, but it should be noticed that although the magnitude of superoxide production differed between the compounds they all showed the same kinetics. This is shown for the three most potent compounds in Fig 2. The time course was characterized by a very short lag phase followed by a rapid increase of superoxide release and a peak of activity was reached after around one minute. This is a response that is typical for most chemoattractants that bind to a neutrophil GPCR and activate the oxidase, and one such, fMLF response, is shown for comparison (Fig 2 inset).

The magnitudes of the responses induced by compound 4 and compound 5 at a concentration of $1 \mu \mathrm{M}$ were in the same level as that induced by WKYMVM $\left(10^{-7} \mathrm{M}\right)$ and fMLF $\left(10^{-7} \mathrm{M}\right)$, two very potent agonists for FPR2 and FPR1, respectively (shown for fMLF; Fig2 inset). The $\mathrm{EC}_{50}$ values for activation of the neutrophil oxidase were in the range $0.1-0.2 \mu \mathrm{M}$ for both compound 4 and 5. Even though the $\mathrm{EC}_{50}$ value for activation of the oxidase with compound 10 was in the same range as the other two, the maximal amount of radicals produced was lower (Fig 2). 


\subsection{The compounds 4, 5, and 10 are not inactivated by reactive oxygen species generated}

\section{by neutrophils}

Neutrophil derived reactive oxygen species are highly reactive not only with bacterial proteins during bacterial clearance process, they could also oxidize and inactive small molecules very rapidly. Accordingly, we recently showed that the FPR agonists fMLF and WKYMVM are rapidly inactivated by ROS producing neutrophils in a process that is dependent on the azurophil granule protein MPO [14, 28]. To determine the sensitivity of the new compounds for neutrophil derived oxygen radicals, we added the compounds 4, 5, or 10 at high concentrations $(10 \mu \mathrm{M})$ to neutrophils. After an incubation period of $10 \mathrm{~min}$, the cells were removed by centrifugation and the agonists remaining in the supernatant after interaction with the neutrophils were used to trigger a new/fresh sample of cells to generate ROS. A high concentration $(10 \mu \mathrm{M})$ of the agonists was chosen for inactivation, making it possible to use a small volume $(0.1 \mathrm{ml})$ of each supernatant, and add that to a new/fresh sample of cells. Inactivation of a compound would then result in a reduced cellular response induced by a cell free supernatant (with $10 \mu \mathrm{M}$ from the beginning), compared to the corresponding control pre-incubated without any cells. the activities induced by the three compounds were, however, basically unchanged after interaction with the neutrophils (Fig 3A, shown for compound 5 ; Table 1) whereas the triggering effect of fMLF in a comparable system was reduced by more than $75 \%$ and a complete inactivation of WKYMVM (Fig 3B; Table 1) was obtained. We know from earlier studies that the inactivation is dependent on the granule enzyme MPO [14], but no MPO secretion was induced by any of the compounds used (data not shown), suggesting that the basal level MPO is sufficient. Moreover, the neutrophil activity induced by a cell free supernatant, originating from a mixture of cells, WKYMVM (an FPR2 agonist) and, compound 5 (primarily an FPR1 agonist; see below) was totally inhibited by 
cyclosporine $\mathrm{H}$ (an FPR1 antagonist), showing that when one sensitive and one stable agonist are added to the cells simultaneously, only one of them "survives".

\subsection{Formyl peptide receptor1 (FPR1) is the preferred receptor for compound 4, 5 and, 10.}

Neutrophils express in addition to FPR2 also the closely related receptor FPR1 and these receptors have the ability to recognize a large range of structurally unrelated agonists that are either specific or overlapping. An agonist that can bind and activate both receptors sometimes has a preference for either of the receptors [29], meaning that one of the receptors is not in use unless the preferred receptor is blocked by a specific antagonist or inhibitor. In order to determine which of the receptors that is used by compound 4,5 and, 10 , we used a couple of earlier characterized receptor antagonists and a receptor specific inhibitor. The receptor specific inhibitors used were cyclosporine $H$ [30, 31] and the PBP10 [31-33], antagonists/inhibitors for FPR1 and FPR2, respectively (Fig 4). The FPR2 specific inhibitor PBP10, is a peptide derived from one of the $\mathrm{PIP}_{2}$ binding domains present in the cytoskeletal protein gelsolin. The FPR1 specific antagonist cyclosporine $\mathrm{H}$ completely abolished the neutrophil response both to compound 4 and 5 as well as to compound 10 (table 2 and shown for compound 5 in Fig 4). No inhibitory effect was obtained with the FPR2 specific inhibitor PBP10, but when the FPR1 antagonist was replaced by the specific FPR2 antagonist WRWWWW a partial inhibition was observed (data not shown). Taken together, these data suggest that all three compounds (4,5 and 10) activate neutrophils preferentially through FPR1 rather than through FPR2.

Using transfected CHO cells stably expressing FPR1, we could show that the three compounds (4, 5 and 10) trigger an intracellular $\mathrm{Ca}^{2+}$ response also in these cells (table 2 and shown for compound 5 in Fig 5), confirming the results obtained with normal neutrophils. 


\subsection{Receptor desensitization and hierarchy}

To further elucidate the receptors involved in the cellular responses induced by three novel compounds used, we performed receptor desensitization experiments using agonist with known receptor specificity. It is well established that neutrophils challenged with one GPCR agonist are non-responsive to a second dose of the same agonist, a process known as homologous desensitization. Accordingly, compounds 4, 5 and 10 induced a homologues desensitization in neutrophils (data not shown). Cells that were desensitized with the FPR1 agonist fMLF were desensitized not only to this agonist, but also to the compound 4, 5 and 10 and the desensitized state was there when the order for agonist addition was reversed, i.e., cells triggered with any of the three compounds were desensitized to fMLF (table 2 and shown for compound 5 in Fig 6A). Neutrophils challenged with any of the three compounds were also desensitized to the FPR2 specific agonist WKYMVM, but when the order was reversed - first WKYMVM and then one of the compounds - the cells were only partially desensitized to the three compounds (Fig 6B). This suggests that all three compounds prefer FPR1 over FPR2.

Neutrophils may also be desensitized heterologously, meaning that an occupied receptor not only desensitize itself but also an adjacent receptor with another agonist specificity. This type of desensitization also disclose a receptor hierarchy, illustrated by the fact that an occupation of FPR1 leads to a desensitization of this receptor as well as CXCR (the IL-8 receptor), whereas occupation of CXCR does not desensitize FPR1 [34, 35]. To further explore hierarchy, we determined the desensitization patterns with compound 4, 5 and, 10, three compounds and the intermediate receptor agonist CXCR as well as the end type receptor C5aR. We show that neutrophils challenged with any of the three compounds were nonresponsive to a second stimulation with IL-8 whereas cells first triggered with IL-8 were fully responsive to compound 4, 5 and 13 (table 2 and shown for compound 5 in Fig 7A) 
suggesting a receptor hierarchy that is in line with the known desensitization model in which the FPRs are superior to CXCR. For comparision, the desensitization pattern obtained when fMLF replaces compound 4, 5 and, 10, and showing that fMLF could desensitize neutrophils to IL-8 but not vice versa, is also shown (Fig 7C).

Neutrophils activated with either of the three compounds were non-responsive also to C5a whereas no such desensitization is obtained when the order of agonist addition is reversed (table 2 and shown for compound 5 in Fig 7B). This type of desensitization pattern is obtained also when fMLF replaces compound 4, 5 and, 10, i.e., fMLF could desensitize neutrophils to C5a, but not vice versa (data not shown). The precise molecular mechanism underlying this cross/heterologous-desensitization is not yet known.

\subsection{The compounds 4, 5, and, 10 are neutrophil chemoattractants}

Having identified three novel neutrophil FPR1 agonists and shown that they have the ability to activate the neutrophil NADPH-oxidase to generate superoxide anions, we next investigated whether they could induce other cellular functions that are induced by most peptide agonists that are recognized by these receptors. Using a trans-well chamber assay system we could show that cells migrated to the lower chamber where the novel compounds were present suggesting that these substances are chemotactic (Fig 8). The positive control peptides fMLF and WKYMVM (at $10 \mathrm{nM}$ concentration) triggered migration under similar conditions (shown for fMLF in Fig 8). Around $3 \%$ of the cells were recovered in the lower compartment when this contained buffer alone, and this value thus represent spontaneous cellular migration (Fig 8). The potency by which compound 5 induced cellular migration was similar to that of the positive control fMLF, but the concentration required to induce this migration was much higher $(1 \mu \mathrm{M}$ compared to $10 \mathrm{nM})$. The two other compounds (4 and 10$)$ were less potent. 


\subsection{The compounds 4,5 , and 10 induce granule mobilization}

Neutrophil activation by chemoattractants is associated with an induction of granule secretion, and such a process leads to a mobilization to cell surface of new receptors. To investigate the ability of these compounds in triggering granule mobilization, we examined the degree of surface exposure of CR3, a marker protein localized in easily mobilizable granules in neutrophils (i.e. secretory vesicles, gelatinase granules, and to some extent specific granules), upon stimulation with various concentrations of the compounds 4, 5, and 10. The chemoattractants fMLF and WKYMVM were used as controls and they both induced a pronounced increased in CR3 exposure, in a concentration dependent manner (Fig 9 inset). Similarly, pre-incubation of cells with either compound resulted in a large increase of CR3 exposure and this increase was also found to be concentration dependent (Fig 9). Compound 4 was found to be the most potent whereas compound 5, the most potent in triggering the production of ROS, was the least potent in mobilizing CR3 (Fig 9). 


\section{Discussion}

Agonists as well as antagonists for FPR2 have been suggested to be of therapeutic value [36, 37], and in addition, if they in one way or another selectively stimulate/inhibit neutrophil functions, they may be used also as research tools [5]. In order to find agonists with this potency, we screened a library of small compounds and several ligands for FPR2 with varying $\mathrm{EC}_{50}$ values were identified. The identification of small-molecule ligands represent an attractive approach to analyze structure and function of FPRs, and in line with this several research articles using the same approach have been published during the last couple of years $[16,38-40]$. Of the compounds that we used and found to activate human neutrophils to produce/release superoxide anions, 5 (4 unique and one enantiomer) have been described earlier. Compound 1 and 2 in this study (Fig 1) are enantiomers of an earlier described FPR2 agonist (Acadia C7; http://www.wipo.int/pctdb/en/wo.jsp?wo=2005047899), that has been shown to dose dependently prevent hyperalgesia induced by carrageenan in a rat model. It should be noticed that large differences have been described for receptor agonists and their enantiomers [41], but in our hands compound 1 and 2 were equally potent, but not among the most potent neutrophil activators in. Compound 3 used in this study is a substituted quinazinolione (QuinC1), that has been described to be chemotactic and induce degranulation in neutrophils [42], but be unable to stimulate superoxide production [15]. We show using a more sensitive technique to detect ROS formation that compound 3 activates the NADPHoxidase in resting as well as primed cells, and we could from experiments with receptor antagonists confirm that FPR2 is the preferred receptor (data not shown). It might well be that ligands may behave differently in functional assays because of their intrinsic ability to induce different receptor conformational changes, but we have not looked into this issue since compound 3 was not among the most potent neutrophil activators and thus not further investigated. Compound 4 is a pyrazolone originally described as an FPR2 agonist that dose 
dependently inhibit chemotaxis of human neutrophils in response to fMLF and IL8 [19]. This is in accordance with earlier studies suggesting that FPR2 is a down-regulating receptor when interacting with the lipoxygenase-derived eicosanoid lipoxin $\mathrm{A}_{4}$ or peptides derived from the $\mathrm{N}$-terminus of the calcium regulated protein annexin I $[11,43]$. We found that compound 4 (Fig 1) activates neutrophils preferentially through FPR1 (see below) which could explain the down-regulating effects on fMLF and IL8 induced chemotaxis, and we also found this compound to be one of the three most potent agonists in our ROS production assay, and based on the potency of activity, the three most potent activators were further characterized.

Many FPR agonists can trigger their own inactivation when interacting with neutrophils (reported here for fMLF and WKYMVM) and the activity of the MPO-hydrogen peroxide system is the basis for the loss of biological activity $[14,44]$. Agents sensitive to this type of inactivation is not restricted to chemotactic factors $[45,46]$, but the three most potent agonists in our ROS production assay (4, 5 and, 10), were all stable in relation to the radicals generated.

Cyclosporin $\mathrm{H}$ is a well established antagonist that abrogates FPR1-dependent responses but not those related to FPR2 [31]. The NADPH-oxidase response induced by the three most potent neutrophil activators, compounds 4,5 , and 10 were all inhibited by cyclosporin $\mathrm{H}$, suggesting that they activate the neutrophil oxidase through FPR1 rather than FPR2. Although it is clear that the three compounds can bind and activate both FPR1 and FPR2, it is obvious that in neutrophils FPR1 is the preferred receptor. This conclusion is based on the following: cross-desensitization was obtained with cells desensitized with fMLF, i.e., the fMLF response was downregulated by the three compounds; the receptor specific inhibitor PBP10 (an FPR2 inhibitor) was without effects whereas the receptor specific antagonist cyclosporin $\mathrm{H}$ inhibited the neutrophil response to the three compounds. The fact that the FPR2 antagonist $\mathrm{WRW}_{4}$ partly inhibited the activity by compound 4,5 an 10 is most probably due to a cross reactivity 
of the antagonist with FPR1, when the agonist used is present in low concentration or has a

lower affinity for the receptor than fMLF. PBP10 is a more specific FPR2 inhibitor, and the fact that this was without effect suggests that FPR1 is the preferred receptor for all three compounds.

We show that all compounds trigger an activation of the neutrophil NADPH-oxidase in neutrophils primed with TNF- $\alpha$. These cells are primed, not only in response to the new compounds, but to various inflammatory mediators, chemoattractants, and other ligands [4750]. The primed response may be a regulatory mechanism, granting a cellular response (such as release of toxic oxygen radicals) only at sites where it is functional and necessary, e.g., in inflamed or infected areas. Although the molecular mechanism(s) responsible for induction of the primed state is unclear, the exposure of new receptors is an attractive model as the molecular basis for an augmented response. We know from an earlier study that intracellular organelles are mobilized to the cell surface during TNF- $\alpha$ priming [13], resulting in an increased exposure of various receptors including CR3, FPR1, and FPR2. The molecular background to the primed response to the new peptides may, thus, be the result of an increased exposure of these receptors.

Our study demonstrates several important functional features of the three compounds characterized: i) they are neutrophil chemoattractants; ii) they mobilize intracellular stores containing the integrin receptor for complement factor iC $3 \mathrm{~b}$; iii) they are potent activators of the NADPH-oxidase, especially in primed neutrophils; iv) they trigger neutrophils through FPR1 and v) they are not inactivated by the reactive oxygen species generated. Availability of potent, cheep, easy to handle, and stable activators of FPRs will undoubtedly be of great help for screening of antagonists for these receptors. The described non-peptide ligands for FPR1 and 2 may also serve as the nucleus for further structural modifications leading to the discovery of more potent and efficacious agonists. This type of work has been performed 
already, using the pyrazolone originally described as an FPR2 agonist, and an even more

potent FPR2 agonist has been described together with a 100 fold less active enatiomer [41]. The selective activation property of Quin-C1 (our compound 3) has also been suggested as an interesting starting structure for future development of small non-peptide molecules that may be clinically useful antagonists for FPR2. The two compounds not earlier described, compound 5 and 10, and found to be agonist for both FPR2 and FPR1, may also be used as starting structures for the development of clinically useful compounds that should be valuable tools also is future studies to reveal structural functional relationships for FPR ligands and their receptors. 


\section{Acknowledgements}

This work was supported by the Swedish Research Council, the Swedish Society for Medical Research, the Medical Faculty of Göteborg, The Swedish government under the ALFagreement, King Gustaf the Vth 80-year foundation and the IngaBritt and Arne Lundberg research foundation.

Torbjörn Morein, Marie Andersson och Katrin Bergdahl at Biovitrum are acknowledged for help in adopting the calcium release assay to the screening platform and Marguerite Luthman for fruitful discussions about signaling. 


\section{Legends to figures}

Fig 1

\section{Chemical structures of compounds 1 through 10.}

The chemical structure for the ten compounds identified in the screening assay as FPR2 agonists. The $\mathrm{EC}_{50}$ values for the compounds, determined through their abilities to induce a $\mathrm{Ca}^{2+}$ response in cells stably expressing FPR2, are also given.

Fig 2

Activation of the neutrophil NADPH-oxidase by the compounds 4, 5, and 10 .

Neutrophils were pre-incubated at $37^{\circ} \mathrm{C}$ for $5 \mathrm{~min}$ and then challenged with the agonists $(1 \mu \mathrm{M}$ final concentration). The extracellular release of superoxide anion was monitored. The time point for addition of the agonist is indicated by an arrow and the amount of superoxide is expressed in arbitrary units. For comparison the response induced by the prototype agonist $\operatorname{fMLF}\left(10^{-7} \mathrm{M}\right.$ final concentration $)$ is shown in the inset.

Abscissa; Time of study (min); ordinate; superoxide production given as light emission and expressed in $\operatorname{cpmx} 10^{-6}$.

Fig 3.

\section{Compound 5 is not inactivated by the neutrophils.}

Neutrophils $\left(10^{7} / \mathrm{ml}\right)$ were incubated at $37^{\circ} \mathrm{C}$ for $10 \mathrm{~min}$ with compound $5(10 \mu \mathrm{M}$ final concentration) or WKYMVM $(1 \mu \mathrm{M}$ final concentration). The cells were then removed by centrifugation and the supernatants were used to trigger freshly prepared cell samples. The cell-free supernatant containing compound 5 induced a respiratory burst (broken line in the upper panel) comparable to the control sample (solid line), whereas no activity was induced 
by the cell-free supernatant containing WKYMVM from the beginning (broken line in the

lower panel). The time point for addition of the supernatant or control agonist is indicated by arrows and the amount of superoxide is expressed in arbitrary units. Abscissa; Time of study (min); ordinate; superoxide production given as light emission and expressed in cpmx $10^{-6}$.

Fig 4

Effects of the PBP 10 (an FPR2 selective inhibitor) and cyclosporine H (an FPR1 selective antagonist) on the NADPH-oxidase activity induced by compound 5.

Neutrophils were pre-incubated at $37^{\circ} \mathrm{C}$ for $5 \mathrm{~min}$ with or without the inhibitors. The concentration of cyclosporine chosen ( $5 \mu \mathrm{M}$ final concentration) inhibited the fMLF induced activity by more than $90 \%$ (upper left) and that of PBP10 $(1 \mu \mathrm{M})$ inhibited the WKYMVM induced activity to the same degree (upper right). Neutrophils were challenged with the FPR1 specific agonist fMLF $\left(10^{-7} \mathrm{M}\right.$ final concentration; upper left), the FPR2 specific agonist WKYMVM $\left(10^{-7} \mathrm{M}\right.$; upper right $)$ or compound $5(1 \mu \mathrm{M}$ final concentration; lower panel $) \pm$ cyclosporine $\mathrm{H}$ or $\mathrm{WRW}_{4}$ (5 $\mu \mathrm{M}$ final concentration), respectively. The extracellular release of superoxide anion was monitored. The time point for addition of the agonist is indicated by an arrow and the amount of superoxide is expressed in arbitrary units.

Abscissa; Time of study (min); ordinate; superoxide production given as light emission and expressed in cpmx $10^{-6}$.

\section{Fig 5}

$\mathrm{A}$ rise in the concentration of intracellular $\mathrm{Ca}^{2+}$ induced by compound 5 in stable transfectants expressing FPR1.

FPR1 transfected cells loaded with the calcium sensitive dye Fluo4 were incubated at $37^{\circ} \mathrm{C}$ for $5 \mathrm{~min}$. The cells were then stimulated with compound 5 (10 nM final concentration) added 
at the time point indicated by the arrow. The changes in cytosolic $\mathrm{Ca}^{2+}$ levels were determined through measurement of the fluorescence emitted at 510-570 nm, during excitation at $488 \mathrm{~nm}$. The result is presented in fluorescence intensities, and a representative experiment is shown.

Fig 6

\section{Receptor desensitization induced by compound 5, fMLF and WKYMVM.}

Neutrophils were pre-incubated at $37^{\circ} \mathrm{C}$ for 5 min and then challenged with the FPR 1 specific agonist fMLF or as indicated by the first arrow (A; solid line). The same cell population was then triggered by compound 5 (second arrow in A, solid line). The agonist order was also reversed; the cells were firs challenged with compound 5 (dotted line) and then with fMLF (dotted line).

The experiment is also shown (B) in which fMLF is replaced by WKYMVM. The time points for addition of the agonists are indicated by arrows and the amount of superoxide is expressed in arbitrary units.

Abscissa; Time of study (min); ordinate; superoxide production given as light emission and expressed in $\operatorname{cpmx} 10^{-6}$.

Fig 7

\section{Receptor desensitization of C5aR and CXCR induced by compound 5.}

Neutrophils were pre-incubated at $37^{\circ} \mathrm{C}$ for $5 \mathrm{~min}$ and then challenged with compound 5 $(1 \mu \mathrm{M}$; in A and B first arrow; broken lines). The same cell population was then triggered with IL8 (second arrow in A) or C5a (second arrow in B). The agonist order was also reversed; the cells were firs challenged with IL8 (solid line in A) or C5a (solid line in B) and then with compound $5(1 \mu \mathrm{M}$ final concentration; second arrow in $\mathrm{A}$ and $\mathrm{B})$. The time points for 
addition of the agonists are indicated by arrows and the amount of superoxide is expressed in arbitrary units. For comparison the response in neutrophils first challenged with fMLF $\left(10^{-7} \mathrm{M}\right.$; in C first arrow; solid line) and then triggered with IL8 (second arrow) is also shown. The agonist order was also reversed; the cells were firs challenged with IL8 (broken line in C) and then with fMLF $\left(10^{-7} \mathrm{M}\right.$ final concentration; second arrow in C).

Abscissa; Time of study (min); ordinate; superoxide production given as light emission and expressed in cpmx $10^{-6}$.

Fig 8

Chemotaxis induced by compound 4,5, and 10 expressed as percent of added cells recovered in the lower compartment of the migration chambers.

Neutrophils were added on top of the filter that separated the upper compartment containing cells but no agonist, from the lower compartment containing the attractant. Three different concentrations of the compounds were used. The migration chambers were incubated at $37^{\circ} \mathrm{C}$ for $90 \mathrm{~min}$ and the fraction cells (percent of those added) in the lower compartments were determined.

Data are expressed as mean migration \pm SEM, of triplicate samples obtained from two experiments. Mann-Whitney $\mathrm{U}$ test was used to analyze statistical significance and $\mathrm{p}$ values < 0.05 were considered significant.

Fig 9

\section{Complement receptor 3 (CR3) mobilization by compound 4, 5, and 10 .}

Neutrophils were incubated for $15 \mathrm{~min}$ at $37^{\circ} \mathrm{C}$ in the presence of compound 4,5 or 10 in concentrations ranging from $0.05 \mu \mathrm{M}$ to $1 \mu \mathrm{M}$. The cells were then fixed through addition of ice-cold paraformyldehyde and stained with phycoeryterin-labelled anti-CR3 (clone 
CBRM1/5, ebioscience) for $30 \mathrm{~min}$ on ice followed by washing and resuspending the cells in

FACS buffer (PBS with $0.1 \mathrm{mM}$ EDTA). The amount of surface exposed CR3 was analyzed by flow cytometry and expressed as percentage of the mean fluorescence intensity (MFI) obtained with control cells incubated under the same conditions but without stimulation. For comparison, surface CR3 exposure upon stimulation with various concentrations of fMLF and WKYMVM was shown in Fig 7 inset. Data are expressed as Mean \pm SEM ( $n=3)$. MannWhitney $U$ test was used to analyze statistical significance and $\mathrm{p}$ values $<0.05$ were considered significant. 


\section{REFERENCES}

1. Murphy PM, The molecular biology of leukocyte chemoattractant receptors. Annu Rev Immunol 12: 593-633, 1994.

2. $\quad$ Miller AF and Falke JJ, Chemotaxis receptors and signaling. Adv Protein Chem 68: 393-444, 2004.

3. Ye RD and Boulay F, Structure and function of leukocyte chemoattractant receptors. Adv Pharmacol 39: 221-89, 1997.

4. Fu H, Karlsson J, Bylund J, Movitz C, Karlsson A and Dahlgren C, Ligand recognition and activation of formyl peptide receptors in neutrophils. J Leukoc Biol 79(2): 247-56, 2006

5. Ye RD, Boulay F, Wang JM, Dahlgren C, Gerard C, Parmentier M, Serhan CN and Murphy PM, International Union of Basic and Clinical Pharmacology. LXXIII. Nomenclature for the formyl peptide receptor (FPR) family. Pharmacol Rev 61(2): 119-61, 2009.

6. Arruda MA and Barja-Fidalgo C, NADPH oxidase activity: In the crossroad of neutrophil life and death. Front Biosci 14: 4546-56, 2009.

7. Nauseef WM, How human neutrophils kill and degrade microbes: an integrated view. Immunol Rev 219: 88-102, 2007.

8. Hayhoe RP, Kamal AM, Solito E, Flower RJ, Cooper D and Perretti M, Annexin 1 and its bioactive peptide inhibit neutrophil-endothelium interactions under flow: indication of distinct receptor involvement. Blood 107(5): 2123-30, 2006.

9. Martin GR, Perretti M, Flower RJ and Wallace JL, Annexin-1 modulates repair of gastric mucosal injury. Am J Physiol Gastrointest Liver Physiol 294(3): G764-9, 2008.

10. Hecht I, Rong J, Sampaio AL, Hermesh C, Rutledge C, Shemesh R, Toporik A, Beiman M, Dassa L, Niv H, Cojocaru G, Zauberman A, Rotman G, Perretti M, 
Vinten-Johansen $\mathrm{J}$ and Cohen Y, A novel peptide agonist of formyl-peptide receptorlike 1 (ALX) displays anti-inflammatory and cardioprotective effects. J Pharmacol Exp Ther 328(2): 426-34, 2009.

11. Serhan $\mathrm{CN}$, Yacoubian $\mathrm{S}$ and Yang R, Anti-inflammatory and proresolving lipid mediators. Annu Rev Pathol 3: 279-312, 2008.

12. Christophe T, Karlsson A, Rabiet MJ, Boulay F and Dahlgren C, Phagocyte activation by Trp-Lys-Tyr-Met-Val-Met, acting through FPRL1/LXA4R, is not affected by lipoxin A4. Scand J Immunol 56(5): 470-6, 2002.

13. Forsman $\mathrm{H}$ and Dahlgren $\mathrm{C}$, Lipoxin $\mathrm{A}(4)$ metabolites/analogues from two commercial sources have no effects on TNF-alpha-mediated priming or activation through the neutrophil formyl peptide receptors. Scand J Immunol 70(4): 396-402, 2009.

14. Forsman H, Salomonsson E, Onnheim K, Karlsson J, Bjorstad A, Leffler H, Bylund J, Karlsson A and Dahlgren C, The beta-galactoside binding immunomodulatory lectin galectin-3 reverses the desensitized state induced in neutrophils by the chemotactic peptide f-Met-Leu-Phe: role of reactive oxygen species generated by the NADPHoxidase and inactivation of the agonist. Glycobiology 18(11): 905-12, 2008.

15. Zhou C, Zhang S, Nanamori M, Zhang Y, Liu Q, Li N, Sun M, Tian J, Ye PP, Cheng N, Ye RD and Wang MW, Pharmacological characterization of a novel nonpeptide antagonist for formyl peptide receptor-like 1. Mol Pharmacol 72(4): 976-83, 2007.

16. Schepetkin IA, Kirpotina LN, Khlebnikov AI and Quinn MT, High-throughput screening for small-molecule activators of neutrophils: identification of novel $\mathrm{N}$ formyl peptide receptor agonists. Mol Pharmacol 71(4): 1061-74, 2007.

17. Sogawa Y, Shimizugawa A, Ohyama T, Maeda H and Hirahara K, The Pyrazolone Originally Reported to Be a Formyl Peptide Receptor (FPR) 2/ALX-Selective Agonist 
Is Instead an FPR1 and FPR2/ALX Dual Agonist. J Pharmacol Sci 111(3): 317-321, 2009.

18. Kirpotina LN, Khlebnikov AI, Schepetkin IA, Ye RD, Rabiet MJ, Jutila MA and Quinn MT, Identification of novel small-molecule agonists for human formyl peptide receptors and pharmacophore models of their recognition. Mol Pharmacol 77(2): 15970.

19. Burli RW, Xu H, Zou X, Muller K, Golden J, Frohn M, Adlam M, Plant MH, Wong M, McElvain M, Regal K, Viswanadhan VN, Tagari P and Hungate R, Potent hFPRL1 (ALXR) agonists as potential anti-inflammatory agents. Bioorg Med Chem Lett 16(14): 3713-8, 2006.

20. Dixon SL, Smondyrev AM, Knoll EH, Rao SN, Shaw DE and Friesner RA, PHASE: a new engine for pharmacophore perception, 3D QSAR model development, and 3D database screening: 1. Methodology and preliminary results. J Comput Aided Mol Des 20(10-11): 647-71, 2006.

21. Abrahamian E, Fox PC, Naerum L, Christensen IT, Thogersen H and Clark RD, Efficient generation, storage, and manipulation of fully flexible pharmacophore multiplets and their use in 3-D similarity searching. J Chem Inf Comput Sci 43(2): 458-68, 2003.

22. Cunningham CC, Vegners R, Bucki R, Funaki M, Korde N, Hartwig JH, Stossel TP and Janmey PA, Cell permeant polyphosphoinositide-binding peptides that block cell motility and actin assembly. J Biol Chem 276(46): 43390-9, 2001.

23. Boyum A, Lovhaug D, Tresland L and Nordlie EM, Separation of leucocytes: improved cell purity by fine adjustments of gradient medium density and osmolality. Scand J Immunol 34(6): 697-712, 1991. 
24. Lundqvist $\mathrm{H}$ and Dahlgren $\mathrm{C}$, Isoluminol-enhanced chemiluminescence: a sensitive method to study the release of superoxide anion from human neutrophils. Free Radic Biol Med 20(6): 785-92, 1996.

25. Dahlgren C, Karlsson A and Bylund J, Measurement of respiratory burst products generated by professional phagocytes. Methods Mol Biol 412: 349-63, 2007.

26. Dahlgren $\mathrm{C}$ and Karlsson A, Respiratory burst in human neutrophils. J Immunol Methods 232(1-2): 3-14, 1999.

27. Betten A, Dahlgren C, Mellqvist UH, Hermodsson S and Hellstrand K, Oxygen radical-induced natural killer cell dysfunction: role of myeloperoxidase and regulation by serotonin. J Leukoc Biol 75(6): 1111-5, 2004.

28. Karlsson J, Bylund J, Movitz C, Bjorkman L, Forsman H and Dahlgren C, A methodological approach to studies of desensitization of the formyl peptide receptor: Role of the read out system, reactive oxygen species and the specific agonist used to trigger neutrophils. J Immunol Methods, 2009.

29. Karlsson J, Fu H, Boulay F, Bylund J and Dahlgren C, The peptide Trp-Lys-Tyr-MetVal-D-Met activates neutrophils through the formyl peptide receptor only when signaling through the formylpeptide receptor like 1 is blocked. A receptor switch with implications for signal transduction studies with inhibitors and receptor antagonists. Biochem Pharmacol 71(10): 1488-96, 2006.

30. Wenzel-Seifert $\mathrm{K}$ and Seifert $\mathrm{R}$, Cyclosporin $\mathrm{H}$ is a potent and selective formyl peptide receptor antagonist. Comparison with N-t-butoxycarbonyl-L-phenylalanyl-Lleucyl-L-phenylalanyl-L- leucyl-L-phenylalanine and cyclosporins A, B, C, D, and E. J Immunol 150(10): 4591-9, 1993. 
31. Stenfeldt AL, Karlsson J, Wenneras C, Bylund J, Fu H and Dahlgren C, Cyclosporin $\mathrm{H}$, Boc-MLF and Boc-FLFLF are antagonists that preferentially inhibit activity triggered through the formyl peptide receptor. Inflammation 30(6): 224-9, 2007.

32. Fu H, Bjorkman L, Janmey P, Karlsson A, Karlsson J, Movitz C and Dahlgren C, The two neutrophil members of the formylpeptide receptor family activate the NADPHoxidase through signals that differ in sensitivity to a gelsolin derived phosphoinositide-binding peptide. BMC Cell Biol 5(1): 50, 2004.

33. Forsman $\mathrm{H}$ and Dahlgren C, The FPR2-induced rise in cytosolic calcium in human neutrophils relies on an emptying of intracellular calcium stores and is inhibited by a gelsolin-derived PIP2-binding peptide. BMC Cell Biol 11(1): 52.

34. Heit B, Tavener S, Raharjo E and Kubes P, An intracellular signaling hierarchy determines direction of migration in opposing chemotactic gradients. $J$ Cell Biol 159(1): 91-102, 2002.

35. Fu H, Bylund J, Karlsson A, Pellme S and Dahlgren C, The mechanism for activation of the neutrophil NADPH-oxidase by the peptides formyl-Met-Leu-Phe and Trp-LysTyr-Met-Val-Met differs from that for interleukin-8. Immunology 112(2): 201-10, 2004.

36. Zhang Q, Raoof M, Chen Y, Sumi Y, Sursal T, Junger W, Brohi K, Itagaki K and Hauser CJ, Circulating mitochondrial DAMPs cause inflammatory responses to injury. Nature 464(7285): 104-7.

37. Dufton $\mathrm{N}$ and Perretti M, Therapeutic anti-inflammatory potential of formyl-peptide receptor agonists. Pharmacol Ther 127(2): 175-88.

38. Arterburn JB, Oprea TI, Prossnitz ER, Edwards BS and Sklar LA, Discovery of Selective Probes and Antagonists for G-Protein-Coupled Receptors FPR/FPRL1 and GPR30. Curr Top Med Chem 9(13): 1227-1236, 2009. 
39. Young SM, Bologa C, Prossnitz ER, Oprea TI, Sklar LA and Edwards BS, Highthroughput screening with HyperCyt flow cytometry to detect small molecule formylpeptide receptor ligands. J Biomol Screen 10(4): 374-82, 2005.

40. Young SM, Bologa CM, Fara D, Bryant BK, Strouse JJ, Arterburn JB, Ye RD, Oprea TI, Prossnitz ER, Sklar LA and Edwards BS, Duplex high-throughput flow cytometry screen identifies two novel formylpeptide receptor family probes. Cytometry A 75(3): 253-63, 2009.

41. Frohn M, Xu H, Zou X, Chang C, McElvaine M, Plant MH, Wong M, Tagari P, Hungate R and Burli RW, New 'chemical probes' to examine the role of the hFPRL1 (or ALXR) receptor in inflammation. Bioorg Med Chem Lett 17(23): 6633-7, 2007.

42. Nanamori M, Cheng X, Mei J, Sang H, Xuan Y, Zhou C, Wang MW and Ye RD, A novel nonpeptide ligand for formyl peptide receptor-like 1. Mol Pharmacol 66(5): 1213-22, 2004.

43. Perretti M and Dalli J, Exploiting the Annexin A1 pathway for the development of novel anti-inflammatory therapeutics. Br J Pharmacol 158(4): 936-46, 2009.

44. Clark RA, Chemotactic factors trigger their own oxidative inactivation by human neutrophils. J Immunol 129(6): 2725-8, 1982.

45. Reumaux D, Hordijk PL, Duthilleul P and Roos D, Priming by tumor necrosis factoralpha of human neutrophil NADPH-oxidase activity induced by anti-proteinase-3 or anti-myeloperoxidase antibodies. J Leukoc Biol 80(6): 1424-33, 2006.

46. Hsieh SC, Yu HS, Cheng SH, Li KJ, Lu MC, Wu CH, Tsai CY and Yu CL, Antimyeloperoxidase antibodies enhance phagocytosis, IL-8 production, and glucose uptake of polymorphonuclear neutrophils rather than anti-proteinase 3 antibodies leading to activation-induced cell death of the neutrophils. Clin Rheumatol 26(2): 21624, 2007. 
47. Almkvist J, Dahlgren C, Leffler $\mathrm{H}$ and Karlsson A, Newcastle disease virus neuraminidase primes neutrophils for stimulation by galectin-3 and formyl-Met-LeuPhe. Exp Cell Res 298(1): 74-82, 2004.

48. Bylund J, Karlsson A, Boulay F and Dahlgren C, Lipopolysaccharide-induced granule mobilization and priming of the neutrophil response to Helicobacter pylori peptide Hp(2-20), which activates formyl peptide receptor-like 1. Infect Immun 70(6): 2908$14,2002$.

49. Bylund J, Pellme S, Fu H, Mellqvist UH, Hellstrand K, Karlsson A and Dahlgren C, Cytochalasin B triggers a novel pertussis toxin sensitive pathway in TNF-alpha primed neutrophils. BMC Cell Biol 5(1): 21, 2004.

50. Karlsson A, Follin P, Leffler H and Dahlgren C, Galectin-3 activates the NADPHoxidase in exudated but not peripheral blood neutrophils. Blood 91(9): 3430-8, 1998. 


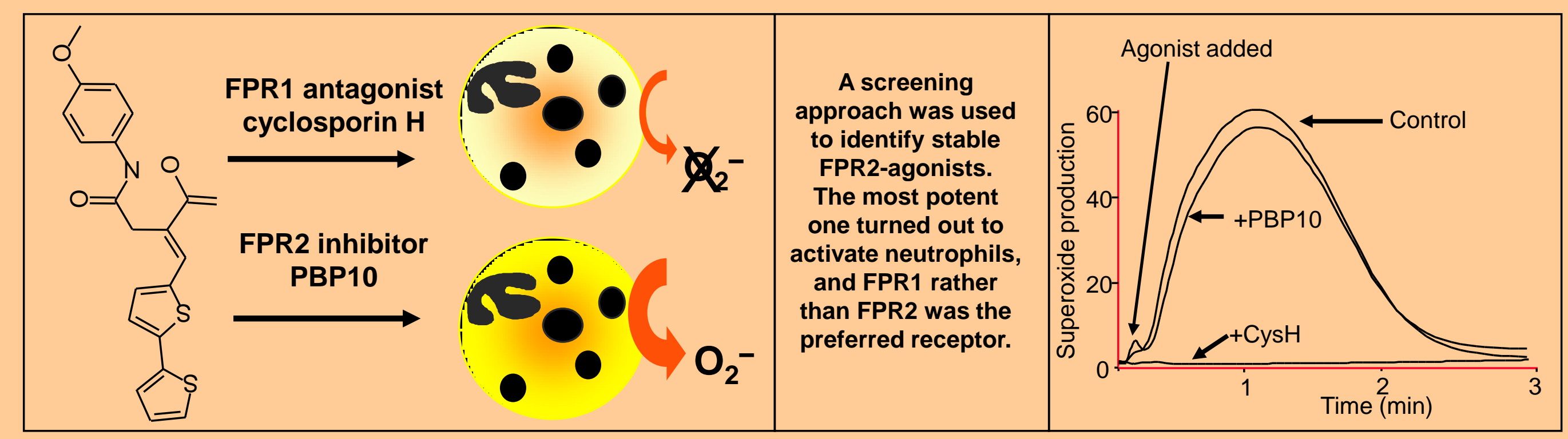

